\title{
Review of Halal Food Standard PBD24: 2007 in Negara Brunei Darussalam towards Quality and Safety Food
}

Assoc. Prof. Dr. Nurdeng Deuraseh ${ }^{1}$ and Negara Brunei Darussalam

${ }^{1}$ Director of Halalan Thayyiban Research Centre Universiti Islam Sultan Sharif Ali (UNISSA)

Abstract

The halal food industry has received a substantial increase in attention from local authorities in recent years, resulting in the creation of an organisation to oversee the sector, design and develop halal food standards to cater the growing demand of consumers, and ensure that halal food is produced in accordance with instructions in the Quran ('Kulu Mimma fi al-Ard Halalan Thayyiban'). Based on this demand, Negara Brunei Darussalam, through the Religious Council, has developed a Halal food standard PBD24: 2007. This paper is an attempt to discuss, highlight and analyze the general guidelines, rules and policies of halal food production based on Halal food

Corresponding Author: Negara Brunei Darussalam nurdeng.deuraseh@unissa .edu.bn

Received: 2 May 2020

Accepted: 4 July 2020

Published: 14 July 2020

Publishing services provided by Knowledge E

(c) Assoc. Prof. Dr. Nurdeng Deuraseh and Negara Brunei Darussalam. This article is distributed under the terms of the Creative Commons

Attribution License, which permits unrestricted use and redistribution provided that the original author and source are credited.

Selection and Peer-review under the responsibility of the ICIEHI Conference Committee. standard PBD24: 2007, and its contribution to global food quality and safety. It was found that Negara Brunei Darussalam owns a comprehensive standard and law to fulfil the need of local and international halal food industry.

Keywords: Halal Food Standard, Negara Brunei Darussalam, Quality and Safety Food.

\section{Introduction}

The word standard implies a variety of meaning when applied to different usage of sentences. (Md Noorsuffian, Y., 2011).In the case of the meaning of standard, it is closely interlinked with achieving a certain level of quality that is set by the concerning authorities i.e., a level of quality or attainment. (https://en.oxforddictionaries.com); something established for use as a rule or basis as a comparison in measuring or judging capacity, quantity, content, extent, value, quality, etc.(https://www.collinsdictionary.com). This paper is an attempt to highlight and discuss the halal food standard of Brunei Darussalam known as the PBD24:2007 towards safety and quality halal food in accordance to Islamic law (hukum syarak), which play as a crucial standard for halal industry players to prepare halal food in Negara Brunei Darussalam. Entrepreneurs must comply with that standard so that the business does not violate the law as well as enable to produce a quality and safety food for local and international customers (Muhammed Salih Al-Munajjid, (2018).

\section{G OPEN ACCESS}




\section{Food Safety According to Good Manufacturing Practice (GMP)}

GMP is stand for Good Manufacturing Practice and form an importance part of overall HACCP food safety system in a food business.(VK Chaudhari, V Yadav, PK Verma, AK Singh (2014), Mohamed Ibrahim Noordin, Wan Azman Wan Ismail (2013). Good Manufacturing Practice can be defined as the operational requirements that food manufacturer need to follow to produce a food safety from any hazard. There are heavy emphasis of Good Manufacturing Practice toward food product or other stuff such cosmetic or medicine.(Mohamed Ibrahim Noordin, Wan Azman Wan Ismail (2013).

One of the main practical benefits of Good Manufacturing Practices is to avoid any hazard or contamination during the processing of the product such as food product, medicine and other. (Mohamed Ibrahim Noordin, Wan Azman Wan Ismail (2013).GMP is usually used in facilities where food product or medicine product is manufactured. Moreover, the condition of drug and cosmetic is established to fulfil the requirement that is required by the legal authorities of the control of drugs and cosmetic. This requirement need to be follow by the manufacturer of the product such as the manufacturer to follow the Good Manufacturing Practice.GMP is very strict on production process such as the cleanliness of the premises, utensils, logistic, transportation and the training that is given to the workers to maintain the good hygiene practices. With this safety programme, the product of that is manufactured will be safe to consume. Good Manufacturing Practice is not only focus on the medicine and drug only but it also focused on food product and beverages.(Mohamed Ibrahim Noordin, Wan Azman Wan Ismail (2013).

Moreover, GMP will substantially increase the quality of the product, this is because GMP programme will make sure the processing method such as the environment of the workplace the condition of machine that is used in the product processing and the design of the workplace. This environment of the product will be safer if GMP is applied because GMP programme will have an inspection on the workplace frequently or based on the complaint by the customer. So, with the safety programme such as GMP will make sure the quality of the product is safe for the customer. The auditor will make an inspection to the design of the workplace such as in the slaughterhouse. If the clean and danger zone is not separated in the building. The inspector will ensure that the slaughterhouse have to separate the safe zone and danger zone to make sure there is no contamination happen that will affect the cleanliness and hygiene of the product.

Other than that, Good Manufacturing Practice (GMP) also can increase revenues and customer satisfaction in using some product. As a consumer, they intend to choose 
a good and safe product rather than unsafe product. So as the safety program that is served by GMP will make sure that the product is safe from any hazard during the processing flow from farm to fork. As the example if a good consumer want to buy a mineral water in the supermarket, they can achieve their satisfaction on the product with checking a GMP logo on the bottle, If they know that a mineral water, they more satisfied about the quality of the mineral water because GMP have make an inspection of the product from the beginning until to the end and to ensure the hazard of the mineral water has been eliminated.

Finally, GMP also has benefits such as efficiencies increase and preparation for HACCP certification. If we want to apply the HACCP, we must comply a GMP system as a foundation because HACCP safety programme is more specific in inspection to analyse hazard that may be occurred in the product. GMP can be as a preparation process for the manufacturer to apply the HACCP System. In order to obtain safety food in according to GMP, the food producers have to fulfil all principles of Good Manufacturing Practice (GMP) as follow:

1. Write a procedure.

The first principle is to develop a procedures in writing or documentation. The purpose is to provide a road map for consistency in performance. Furthermore, written procedure allows to allow standard for the workplace is established. It also ensure that job procedure is performed in the same way each time. This method will followed the step as set out in the written instruction.

2. Follow the procedures.

The procedure that has written will be effective if they are followed to the letter. It is important to follow the procedures and do not do modifications or skip the steps that have been state in the procedure. The consistency in product quality may be change if the procedures are not followed

\section{Documentation.}

The third principles is refer for prompt and accurate documentations of work, thus allowing for compliance with regulations and the ability to trace any problems.Furthermore, an accurate record provide a method to evaluate or trace what happened if there are any problem during process flow or complaint regarding to the product This record keeping also chronicles the precise steps is taken relating to GMP regulations

4. Validating work. 
GMP principles also highlight the important of validating that all system and process are working as they are meant to be. This achieved through documentation and properly following the written procedures.thus ensuring that quality and consistency are carried out according to plan.

5. Facilities and equipment.

The fifth principles highlighted the importance of the integrating productivity, product quality and employee safety into design and construction of the company facilities and equipment. This reinforces the goals to make sure the product is safe at all stage in the production flow.

6. Maintenance.

Equipment and facilities must be properly maintained with documented written record to backup up any work done. This will minimize the any hazard and avoid any potential issues relating to the contamination and quality control of the product.

7. Job competence.

Job competence must be clearly demonstrated by each employee relating to his/her job.GMP requires an employee to be completely competent in their role. It is important to develop job competencies in pale relating to each job

8. Avoiding contamination.

This principle to make sure a product is protected from contamination. The first step in achieving his principle is to make sure the workplace is practicing a good cleanliness as a daily habit. Since the degree of cleanliness needed depends on the type of product being manufacture standard must to be made to ensure the appropriates cleanliness are followed

9. Quality control.

This principle involved building quality intro product via the systematic control of components and process to each product. Quality control includes such as manufacturing, packaging, labelling, distribution and marketing. It can cover all these area and keeping accurate, timely record quality is built into all stage in processing flow.

10. Audits.

Finally, the way to determine how well GMP is implemented is with conduct planned periodic audit to access the success of compliance with GMP regulations. Inspection may be on the building of the manufacturing process, machine that 
used utensils and on the design of the build. Audits can be implemented in order to prevent any hazardous substances contaminate during the processing of the product. The auditors must audit the company with following the procedure that has stated in the document.

\section{Food Safety according to Hazard Analysis Critical Con- trol Point (HACCP)}

The HACCP system is a scientific and systemactic approach to identify, assess and control hazards in the food production process, from purchasing, receiving, transportation, storage, preparation, handling, cooking to serving (Dimitrios P., Kafetzopoulos,Evangelos L., Psomas, Panagiotis D., Kafetzopoulos. (2013); L. Manning \& R.N. Baines (2004). To understand clearly what HACCP is, so, the following are among related definitions in HACCP:

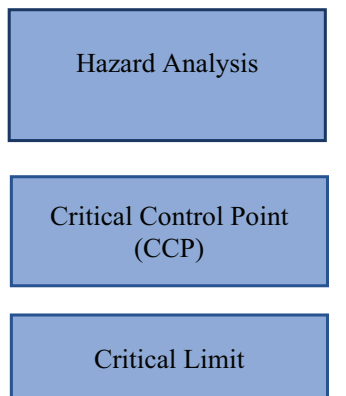

Process flow

HACCP plan

Hazard

Corrective action

Verification

Validation

HACCP team
The process of collecting and evaluating information on hazards and conditions loading to their presence to decide which are significant for food safety and therefore should be addressed in the HACCP plan

A step at which control can be applied and is essential to prevent or eliminate a food safety hazard or reduce it to an acceptable level

A criterion which separate acceptability from unacceptability

A systematic representation of the sequences of steps or operation used in the productions or manufacture of particular food item

A document prepared in accordance with the principles of HACCP

A biological, chemical or physical agent in a condition of food with the potential cause an adverse health effect

Any action to be taken when the result of monitoring at the $\mathrm{CCP}$ indicate loss of control

The application of method, procedures, tests and other evaluations. In addition to monitor and to determine that compliance with HACCP plan

Obtaining evidence that the elements of the HACCP plan are effective

A group of people consists of production manager, engineer, microbiologist and QA staff who are responsible to arrange the plan for HACCP process 


\subsection{HACCP has seven principles (Guest Editorial. (2014):}

\subsubsection{Principle 1: Conduct a Hazard Analysis}

In this principle, to conduct a hazard analysis they need to analysis for the Food Safety Hazard which is anything present in food with the potential to harm the consumer, either by causing illness or injury. Food safety hazard can be in three conditions which are physical, biological and chemical hazard. Firstly, examples of physical hazards are glass, metal, stone, woods, bones and etc. Secondly, examples of biological hazards are pathogenic bacteria, viruses, parasites and fungi. Finally, examples of chemical hazards are pesticides, antibiotics, toxins, cleaning fluids and veterinary drugs residue. The HACCP team should construct a process flow diagram which identifies all the hazard that potentially contaminate during processing and producing or in the ingredients used. To help the process of evaluation, "Hazard Analysis Worksheet" need to be use as in attachment. (Dimitrios P., Kafetzopoulos,Evangelos L., Psomas,Panagiotis D., Kafetzopoulos. (2013);Jose ' E. Pardo, Vin $\iota$ 'cius Reis de Figueire^do, Manuel A', Ivarez-Ortı', Diego C. Zied, Jesu's A. Peñaranda, Eusta'quio Souza Dias, Arturo PardoGiménez (2013).

\subsubsection{Principle 2: Identify Critical Control Point}

The HACCP team needs to determine whether the activity or control measure is critically essential. How to determine is it necessary or not? Critical Control Point are identified through the use of "CCP Decision Tree. An example of CCPs is the inspection of goods on delivery and before use includes temperature checks where applicable.

\subsubsection{Principle 3: Establish Critical Limit}

As in the definition mentioned earlier, critical limit is a criterion which separates acceptability from unacceptability. Thus, critical limit will describe the difference between safe and unsafe products at CCP. Often, critical limit is something or standard that is measurable and observable. Usually, when we talk about the critical limit, we need to determine the maximum limit and minimum limit of an activity such as limiting the temperature. Instead of stating "food must be thoroughly cooked" the standard should be stated " Heat rapidly to a required safe internal temperature of $165^{\circ} \mathrm{F}$ for 15 seconds". If not controlling the critical limit it might cause a hazard to the safety of the food. Thus, 
it is important to establish the critical limit and be more specified on what we need to control at the critical limit.

\subsubsection{Principle 4: Monitor Critical Control Point}

After all the first three principles applied, then the process of monitoring can be done. The HACCP team must know on what are they going to monitor and they must put on conditions or regulations in monitoring every CCPs. Monitoring is the process of observing and measuring to ensure that the CCPs are in the right condition and at the end of the process it give a right and clear record for the verification process. They must determine whether all the criteria and standards are being met at all CCPs and throughout the process. For example, determining how \& by whom cooking time \& temperature are monitored. Monitoring method can be done through:

1. Physical measurement (dimension, colour, appearance)

2. Visual observation (workers practices, inspect raw materials)

3. Sensory evaluation (odour, colour, texture)

4. Chemical measurement $(\mathrm{pH}$, aw, salt content, etc.)

5. Temperature checking (Using thermometer to check the temperature)

\subsubsection{Principle 5: Establish Corrective Action}

Corrective action must be done of there are misconduct on a certain process that have been regulated. Even though HACCP was designed for the safety of the food product sometimes there might misconduct on the first and on the third principles. Corrective action must be done so that it can eliminate the hazard effectively. For example, a corrective action for food not being held at a proper warming temperature of $140^{\circ} \mathrm{F}$ $\left(60^{\circ} \mathrm{C}\right)$ may be different depending on how long the food has been at the improper temperature.

\subsubsection{Principle 6: Verification}

This principle verifies that the HACCP food safety system is working accordingly to the plan. The purpose of documentation system is to ease the process detecting the food the contaminated product in a short time and to revise and arrange the HACCP more systematic. 


\subsubsection{Principle 7: Record Keeping}

Written records are very important as if there are cases involving food borne illness. Records may provide proof. Establishing record keeping system can be simple, quick system such as printed temperature forms in which employees can record their compliance with standards at CCPs. Record keeping are the proof that the HACCP system are working accordingly to the standards.

\section{Results and Discussion: PBD 24: 2007}

The main contents of Brunei Halal food standard are as follow:

1. Sources of the Halal foods and drinks

2. Slaughtering

3. Stunning

4. Scalding

5. Inspection

6. Product manufacturing, processing, handling, storage, transportation and distribution

7. Product storage, display and servings

8. Hygiene, sanitation, sanitization and food safety

9. Packaging and

10. Labeling

\subsection{Definition of Halal food}

Technical definition: Halal foods are foods that are permissible based on Islamic law. While unlawful or prohibited food is called haram (Jabatan Mufti Kerajaan. 2007).

Operational definition: Halal foods mean food fit for human consumption and permitted by hukum syarak and fulfill the following conditions:

1. the food or its ingredients that do not contain any parts or products of animals that are non-halal to Muslims according to hukum syarak or products of animals which are not slaughtered according to hukum syarak; 
2. the food does not contain any ingredients that are najs according to hukum syarak;

3. the food that is safe and not harmful;

4. the food that is not prepared, processed or manufactured using equipment that is contaminated with things that are najs according to hukum syarak;

5. the food or its ingredients do not contain any human parts or its derivatives that are not permitted by hukum syarak;

6. during its preparation, processing. Packaging, storage or transportation, the food is physically separated from any other food that does not meet the requirements stated in items (a), (b), (c), (d) or (e) or any other things that have been decreed as najs by hukum syarak (PBD 24:2007).

Halal Certification is defined as a document that guarantees that the products and services aimed at the Muslim population, meet the requirements of hukum syarak or Shariah Law. It is a process which ensures the features and quality of the product (Zainalabidin Mohamed, et. al.(2008); Amin Hosni, (2013).

\subsection{Slaughtering}

According to hukum syarak the slaughter act shall sever the trachea (halqum), oesophagus (mari') and both the carotid arteries and jugular veins (wadajain) to hasten the bleeding and death of the animals (PBD 24:2007).

Based on this standard, the procedures of slaughtering are: -

1. Mechanical slaughter of halal animals is prohibited.

2. The act of slaughtering shall be done with niyyah (intention) and the slaughterer is well aware of his action.

3. The purpose of slaughtering is only for Allah and not for other purposes.

4. The phrases (In the name of Allah Most Gracious, Most Merciful) must be invoked immediately before the slaughtering of each animal.

5. Slaughtering must be done only once to each animal. The 'sawing action' of the slaughtering is permitted as long as the slaughtering knife must not be lifted off the animal during the slaughter.

6. The act of halal slaughter shall begin with an incision on the neck at some point just below the glottis (Adam's apple) and after the glottis for long necked animals. 
7. The slaughter act shall sever the trachea (halqum), oesophagus (mari') and both the carotid arteries and jugular veins (wadajain) to hasten the bleeding and death of the animals. The bleeding shall be spontaneous and complete.

\subsection{Halal Animals}

According to PBD 24:2007 animals can be divided into two categories namely land animals and aquatic animals. The general rule in Islamic Law is that all animals are allowed to be used for food except for those that are expressly forbidden in the Qur'an or the Prophet's traditions. Any animal that is not specifically forbidden in the Qur'an and the Prophet's traditions is considered lawful for Muslims to eat. For land animals to be lawful, two conditions must be met:

1. They must be considered lawful for their flesh to be used for food.

2. They must be hunted or slaughtered according to Islamic law (Shari'ah).

The forbidden land animals to be consumed by Muslims are;

1. Pigs, indeed any of their body parts and by-products, are considered 'filthy' in Islam and thus forbidden for human consumption. As the Qur'an states in Surah al-Maaidah verse 3 , roughly translated:

"Forbidden to you for food are dead animals, blood and the flesh of swine."

2. All meat eating animals, whether they are large, such as lions and tigers, or small, such as cats and dogs are also included in this category. As the Prophet "The Prophet SAW forbade the eating of wild animals having fangs" (Sahih AlBukhari Hadith 7.672)

3. All predatory birds, such as falcons and eagles. As the Prophet said:

"Allah's Messenger (saws) declared domestic asses, the flesh of mules, every beast of prey with fang, and every bird with a talon (claws of birds of prey) to be unlawful." (Al-Tirmidhi Hadith 4129)

4. Insects: All land insects are not lawful because they cannot be slaughtered, with the exception of locusts, as the Prophet 㪇数 said:

"Made lawful for you is the flesh of two dead animals: locusts and fish." (Sunan Ibn Maajah: 3218) 
5. Snakes and Mice: These are also considered unlawful and Islam even goes as far as to command us to kill them. The Prophet 㪇

"There are five animals for which there is no blame on the one who kills them even if he is in a state of consecration for the pilgrimage (ihraam): crows, kites (hawk-like birds), mice/rats, scorpions and mad dogs." (Saheeh Al-Bukhari: 3136; Saheeh Muslim: 1198)

6. Domestic donkeys, which are generally used in the countryside for riding and carrying loads. The Prophet

"Messenger of Allaah (peace and blessings of Allaah be upon him) forbade eating the flesh of domestic donkeys" (Bukhaari, 3982; Muslim, 1941)

\section{Aquatic Animals}

Seafood comes from edible sea plants as well as aquatic animals, which live only in water for most or all of their lives. The term seafood also applies to any freshwater life eaten by humans; therefore, all edible aquatic life can be referred to as seafood. (Muslim Guide, article on "Seafood and Land animals", Available at: https: //newmuslimguide.com/en/your-food-and-drink/65, (Browsed on 29/03/2018).

All types of sea plants as well as aquatic animals are permissible to be used for food, whether they are caught or found dead, unless they are hazardous to life or health. As the Qur'an states, in Surah al-Maaidah:96, roughly translated: "Anything you catch in the sea is lawful for you, and so is all food from it."

The phrase 'anything you catch' in the above verse refers to aquatic animals that are caught alive, while the word 'food' refers to dead aquatic animals that are washed ashore. However, everything in the sea is halal and does not need any slaughtering. Allah says in the Qur'an in Surah al-Maidah: 96, roughly translated: "Lawful to you is (the pursuit of) water game and its use for food - for the benefit of yourselves and those who travel..."

Aquatic animals that live both on land and water such as crocodiles, turtles and frogs are not halal. The correct view of eating crocodile is that eating these is not allowed, because they have fangs and live on land - even though they may spend a lot of time in the water - so precedence should be given to the reason for forbidding it (it is a land animal that has fangs). (Muhammed Salih Al-Munajjid, article on "Food \& Nourishment", available at https://islamqa.info/en/1919, browsed on $29 / 03 / 2018$ ).

While in the case of frogs: it is not permitted to eat them because the Prophet (peace and blessings of Allah be upon him) forbade killing them. Messenger 
of Allah forbade the killing of frogs (Saheeh al-Jaami, 6970). The rule is that everything which we are forbidden to kill, we are not allowed to eat; if we are allowed to eat it we are allowed to kill it (Muhammed Salih Al-Munajjid, article on "Food \& Nourishment", available at https://islamqa.info/en/1919, browsed on 29/03/2018).

\subsection{Packaging}

According to PBD 24:2007, packaging shall be suitably packed using packaging materials that fulfill the following requirements:

1. the packaging materials shall not be made from raw materials that are decreed as najs by hukum syarak;

2. the packaging material is not prepared, processed or manufactured using equipment that is contaminated with things that are najs as decreed by hukum syarak;

3. during the preparation, processing, storage or transportation of the packaging material, it shall be physically separated from any other packaging material that does not meet the requirements stated in item a) or b), or any other things that have been decreed as najs by hukum syarak; and

4. the packaging material does not contain any raw materials that are considered hazardous to human health.

5. packing process shall be carried out in clean and hygienic manner and in sound sanitary conditions.

\subsection{Labelling}

Labelling material used in direct contact with the product shall be non-hazardous and not made from raw materials that are decreed as najs by hukum syarak. Each package shall be marked legibly and indelibly or a label shall be attached to the package, with the following information:

1. name of the product;

2. net content expressed in metric system (SI units);

3. name, address and trademark of the manufacturer of local origin; 
4. name and address of importer and/or local distributor in the case of imported food;

5. list of ingredients and shall be specified in descending order or the proportion by weight;

6. code number identifying date and/or batch number of manufacture and expiry date; and

7. country of origin.

8. For primary meat products, in addition to requirements specified in 3.6.4, the label or mark shall also include the following information:

9. date of slaughter; and

10. date of processing.

\subsection{Drinks}

All kinds of water and beverages are halal as drinks except those that are poisonous, intoxicating or hazardous to health (PBD 24:2007).

\subsection{Genetically Modified Organisms (GMOs)}

Food and drinks containing products and/or by-products of Genetically Modified Organisms (GMOs) or ingredients made by the use of genetic material of animals that are non-halal according to hukum syarak are not halal. (PBD 24:2007)

\subsection{Food Additives}

It is important to ensure that the food additives are from acceptable sources and processed according to halal requirements without the use of alcohol-based carries. (PBD 24:2007).

\subsection{Requirements / Halal management / Responsibility}

None specified but it must comply with the legislation, including other relevant requirements, currently in force in Brunei Darussalam, as per clause 3.9 of PBD 24:2007. 


\subsection{Premises}

None specified but it must comply with the legislation, including other relevant requirements, currently in force in Brunei Darussalam, as per clause 3.9 of PBD 24:2007.

\subsection{Devices, Utensils, Machines and Processing Aids}

1. Shall be designed and constructed to facilitate cleaning;

2. Shall not be made of or contain any materials that are decreed as najs by hukum syarak;

3. Shall be used only for halal food;

4. Devices, utensils, machines and processing aids which were previously used or in contact with pork/dog meat and its derivatives shall be washed and ritually cleansed as required by hukum syarak;

5. This procedure shall be supervised and verified by the competent Islamic Authority;

6. The devices are not allowed to be interchangeably used to process halal food and non halal foods.

\subsection{Hygiene, Sanitation and Food Safety}

Producers shall implement measures to:

1. Control contamination by pesticides, chemicals and other veterinary drugs;

2. Control plant and animal health, to ensure no threat to human health;

3. Ensure no contamination through pests and faecal matters;

4. Manage waste efficiently;

5. Ensure that harmful substances are stored carefully;

6. Ensure no contamination by matters such as plastic, glass, harmful gas / fumes, unwanted chemicals and excessive additives;

7. Ensure that halal foods are prepared/processed/packed etc. in compliance with the Codex of General Principles on Food Hygiene and other relevant Codex Standards 


\subsection{Processing of Halal Food}

Products are prepared, processed or manufactured using equipment and facilities free from contamination with najs as decreed by hukum syarak. Throughout the process chain, all halal foods must be separated from any other food that does not meet the requirements specified above, or any other things decreed as najs by hukum syarak.

\subsection{Storage, Transportation, Display, Sale and Serving of Halal Food}

All halal food stored, transported, displayed, sold and/or served shall be categorized and labelled halal;

It must be segregated at every stage to prevent from being mixed or contaminated with non-halal things

\subsection{Packaging, Labelling \& Advertising}

Packaging / labelling materials not made from raw materials which are najs or hazardous to human health;

Preparation, processing, storage or transportation of the packaging / labeling material must be physically separated anything decreed as najs by hukum syarak. Packaging / labelling must be carried out in clean, sanitary and hygienic conditions.

Information necessary and legibly marked in the label / packaging are as follows:

1. Name of product

2. Nett content;

3. Name, address and trademark of the manufacturer of local origin

4. Name and address of importer and / or local distributor in the case of imported food

\subsection{Alcohol}

Alcohol is not allowed in food and beverages 


\subsection{Genetically Modified Food}

Genetically Modified Food (GMF) is non-halal if the genetic materials are from non-halal animals, such as;

1. Pigs

2. Dogs

3. Animals with long pointed teeth or tusks such as tigers, bears, elephants, cats, monkeys. Etc.

4. Predatory birds such as eagles

5. Pests, such as rats, centipedes, scorpions, snakes, crows, lice, worms, fly, etc.

6. Creatures prohibited to be killed in Islam, such as ants, bees, woodpeckers, etc

7. Amphibians

\subsection{Mechanical Slaughter}

Mechanical slaughter of halal animals is prohibited.

\subsection{Stunning}

Stunning is permitted if;

1. It only temporary immobilizes, nit kill the animal;

2. Does not penetrate or break the animals' head;

3. Does not cause permanent physical or brain damage to the animal.

\section{Conclusions}

It is known that through the regulation of Halal Standard in Brunei Darussalam lots of benefits can be seen in various parts of the society. This regulation not only benefits the community as a whole but also on certain concerning authorities and individuals, especially those involved in the handling of food industries in which it can ensures for supply chain integrity; improved clarity and enhance consumer confidence. The requirement and rules in both PBD 24:2007 must take into consideration while dealing with halal product in Negara Brunei Darussalam for safety and quality foods. 


\section{References}

[1] Hosni, A. (2013). Brunei Workshop On Halal Certification Gets Under Way. Retrieved from halalfocus.net/brunei-workshop-on-halal-certification-gets-under-way/.

[2] Dimitrios P., et al. (2013). Measuring The Effectiveness Of The HACCP Food Safety Management System. Elsevier.

[3] Guest Editorial. (2014). Haccp-Based Food Safety Management Systems: Great In Theory But Can We Really Make Them Work In Practice?. Perspectives in Public Health, vol. 134, issue 4.

[4] Rezai, G., et. al. (2009). Concerns For Halalness Of Halal-Labelled Food Products Among Muslim Consumers In Malaysia: Evaluation Of Selected Demographic Factors in Economic and Technology Management Review, vol. 4, pp. 65 - 73.

[5] Kerajaan, J. M. (2007). Isu-Isu Produk Halal. Brunei Darussalam: Jabatan Mufti Kerajaan, Jabatan Perdana Menteri.

[6] Pardo, J.E., et al. (2013). Application Of Hazard Analysis And Critical Control Points (HACCP) To The Cultivation Line Of Mushroom And Other Cultivated Edible Fungi. Indian Journal of Microbiology, vol. 53, issue 3, pp. 359-369, doi 10.1007/s12088013-0365-4.

[7] Hanzaee, K.H. and Ramezani, M.R. (2011). Intention To Halal Products In The World Markets. Interdisciplinary Journal of research in Business, vol. 1, issue 5, pp. 1-7.

[8] Kementerian. (2011). Retrieved December 1, 2011 from http://www.religiousaffairs.gov. bn/index.php?ch=bm_about_div\&pg=bm_div_syariah\&ac=1619

[9] Manning, L. and Baines, R.N. (2004). Effective Management Of Foodsafety And Quality. British Food Journal, vol. 106, issue 8, pp. 598-606.

[10] Noorsuffian, Y.N. (2011, July). Halal Standards in Brunei. Paper presented at MTCP Training Program on Halal Standards and Conference Infrastructure for OIC Countries, Nilai, Malaysia.

[11] Mustaffa, M.M.H. (2013). Keprihatinan Masyarakat Islam Terhadap Makanan Halal Di Negara Brunei Darussalam. (Thesis, Sarjana Pengajian Islam: Universiti Kebangsaan Malaysia, 2013).

[12] Noordin, M.I. and Ismail, W.A.W. (2013). Importance And Globalization Status Of Good Manufacturing Practice (GMP) Requirements For Pharmaceutical Excipients. Saudi Pharmaceutical Journal, doi.org/10.1016/j.jsps.2013.06.003.

[13] Al-Munajjid, M.S. (2018). Food \& Nourishment. Retrieved from https://islamqa.info/ en/1919. 
[14] Muslim Guide, (2018). Seafood and Land Animals. Retrieved from https:// newmuslimguide.com/en/your-food-and-drink/65.

[15] The Religious Council, Negara Brunei Darussalam. (2007) Brunei Darussalam Standard Halal Food (PBD24:2007), $\left(\right.$ ( $^{\text {st }}$ ed.). The Religious Council: Brunei Darussalam.

[16] Chaudhari, V.K., et al. (2014). A Review on Good Manufacturing Practice(GMP) for Medicinal Products. PharmaTutor, vol. 2, issue 9, pp. 8-19.

[17] Mohamed, Z. et al.(2008). Halal Logo and Consumers' Confidence: What are the important factors?. Economic and technology Management Review, vol. 3, pp. 3745. 